\title{
原著
}

\section{子宮内膜細胞診に出現する正常子宮内膜腺細胞塊と 正常子宮内膜間質細胞塊に関する検討}

\author{
北里研究所メディカルセンター病院検查科 ${ }^{11}$, 同 病理部 ${ }^{21}$, 同 産婦人科 ${ }^{3)}$, 北里大学医学部産婦人科 ${ }^{4)}$ \\ 今井 忠朗 ${ }^{1)}$ 横野 秀樹1) 本告 匡 ${ }^{2)}$ 泉 貴文 ${ }^{3)}$ \\ 源田 辰雄 ${ }^{3)}$ 蔵本 博行 ${ }^{4)}$
}

エンドサイトを用いて採取された無病正常例 354 例の内膜細胞診標本を詳細に観察し, 子宮内膜 腺細胞塊 normal glandular cell cluster ( $\mathrm{n}-\mathrm{GCC}$ ) と子宮内膜間質細胞塊 normal stromal cell sheet $(\mathrm{n}-\mathrm{SCS})$ に注目し，これを規定した。また，内膜細胞診標本 1 枚あたりにみられた n-GCC, $\mathrm{n}-\mathrm{SCS}$ の出現数, 出現頻度を検討し, 以下の結果を得た.

(1) 年齢別に検討したところ, n-GCC は 20 歳代, 30 歳代, 40 歳代において出現数, 出現率とも に多く認められ，50歳代以後では有意に漸減していた（p<0.01）。 n-SCS も同様減少したが, 60 歳以後で，n-GCC に比べ一年代遅かった（p<0.01）。(2) 性周期別に検討した 177 例では, 分泌期 に比べ増殖期で $\mathrm{n}-\mathrm{GCC}$ の判別が容易であり, 出現数も有意に多かった $(\mathrm{p}<0.025)$. (3) 閉経前後 で検討した 270 例では, 閉経後n-GCC の平均出現率が 1.7 個であり, 閉経前 10.1 個に比べ著し く少なかった $(\mathrm{p}<0.01)$.

以上，正常内膜細胞診に出現する細胞塊を n-GCC, n-SCS として把握し，年齢，性周期，閉経 の有無によるそれらの出現パターンを理解しておくことは，ともすれば細胞診断が難しい子宮内膜 異型増殖症や分化型子宮内膜癌の早期発見に役立つ基礎的資料となり得ると考える.

Key words : Endometrium-Cytology-Endocyte

\section{I. はじめに}

子宮内膜細胞診は, 子宮内膜癌の増加に伴い広く一

Cytological study of endometrial cell cluster

Tadaaki IMAI'), C.T., I.A.C., Hideki YOKONO' ${ }^{1)}$, C.T., I.A. C., Tadashi MOTOORI'), M.D., Takafumi IZUMI'), M.D., Tatuo GENDA ${ }^{3)}$, M.D., Hiroyuki KURAMOTO ${ }^{4)}$, M.D., F.I.A. C.

${ }^{1)}$ Department of Clinical Laboratory, ${ }^{2}$ Department of Pathology, ${ }^{3}$ Department of Obstetrics and Gynecolgy, Kitasato Institute Medical Center Hospital

${ }^{4}$ Department of Obstetrics and Gynecolgy, Kitasato University School of Medicine

論文別刷請求先 364 北本市荒井 60100 北里研究所メ ディカルセンター病院検查科病理 今井忠朗

平成 8 年 1 月 31 日

平成 8 年 4 月 12 日
般に実施されるようになってきているが, 子宮内膜異 型増殖症や分化型内膜腺癌などの診断は現在でもしば しば困難なことがある。その原因のひとつとして，内 膜細胞診では複雑な集塊が多数出現することが多く, 細胞個々での診断が困難(1)である場合が多いためと考 えられる。

そこで子宮内膜異型増殖症, 分化型子宮内膜癌の診 断のための基礎的情報として, 正常内膜細胞診におい て日常遭遇することの多い, 内膜細胞集塊を子宮内膜 腺細胞塊 (n-GCC, nomal glandular cell cluster) と 子宮内膜間質細胞塊 (n-SCS, normal stromal cell sheet）の $2 つ に$ 分け詳細に分析し, これらの出現頻 度を, 年齢別, 性周期別 (増殖期, 分泌期), さらに 閉経前後について検討した。 


\section{II. 対象と方法}

\section{1. 検討対象}

1989 年 4 月から 1993 年 5 月までの過去 4 年 1 力月 の間に, 北里メディカルセンター病院産婦人科を受診 乙た無病正常者 354 例を対象に, 年龉別(20歳代 8 例，30 歳代 36 例, 40 歳代 190 例, 50 歳代 83 例, 60 歳代 15 例，70 歳代 22 例）に検討した。さらに，354 症例の中から, 性周期の明らかな 177 例（増殖期 90 例, 分泌期 87 例), また閉経の有無の明らかな 270 例 を(閉経前 218 例, 閉経後 52 例) 無作為に選別して 検討した。これらの症例からエンドサイトで採取した 内膜細胞をスライドグラスに塗抹し，型のごとくパパ ニコロウ染色を行い顕徴鏡下で観察した。なお，症例 ごとの標本枚数は 1 2 (平均 1.1) 枚である。

\section{2. 検討項目}

観察にあたっては, 特に以下に規定する子宮内膜腺 細胞塊 (n-GCC) および子宮内膜間質細胞塊 ( $\mathrm{n}$ SCS）に注目し，標本 1 枚あたりでの，これら細胞塊 の出現数を算出し分析した。統計学的有意差は $\mathrm{t}$ 検定 により判定した。

\section{3. 子宮内膜腺細胞塊 (n-GCC) と子宮内膜間質} 細胞塊（n-SCS）の定義

1) 子宮内膜腺細胞塊 ( $\mathrm{n}-\mathrm{GCC}$ ) (写真 1.3.5. 7.9. 11)

異型を認めない細胞からなる細胞集塊で, その長さ は一定しないが長軸方向の辺緑で腺上皮細胞の柵状配 列で裹打ちされた導管状集塊を n-GCCとした。

2) 子宮内膜間質細胞塊 (n-SCS) (写真 2. 4. 6. 8. 10)

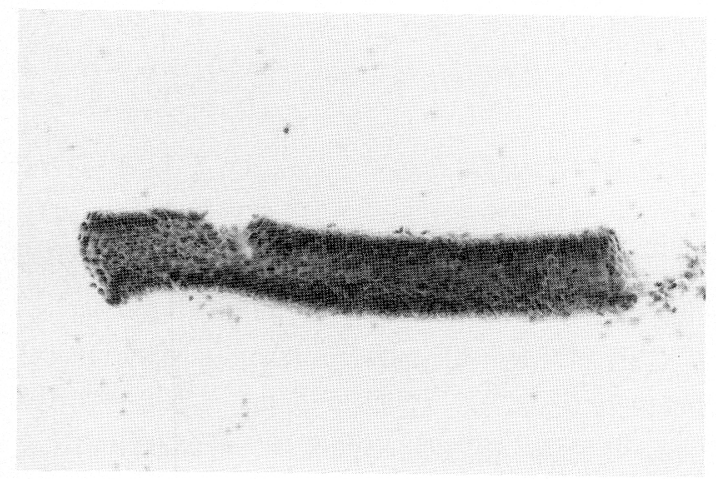

写真 1 増殖期前期. 異型を認めない筒状, 導管状を示した n-GCC (Pap. 染色，×20）
異型を示さない細胞集団で, 細胞配列は平面的な主 として間質細胞加らるシート状ないし，ときに集塊 状を示す細胞集塊をn-SCSとした。集塊の形と大き さはさまざまである。同一集塊内に n-GCC の部分と n-SCS の部分が混在, 移行している場合は, n-GCC を重視し $\mathrm{n}-\mathrm{GCC}$ に分類した。

\section{III. 結果}

\section{1. 内膜細胞集塊の形態的特徵}

1) 増殖期内膜

（1）増殖期前期：n-GCC は導管状を呈し 2 ，集塊 の境界は明瞭で，最外層の細胞は規則的に集塊の長軸 に沿って柵状配列学示す。その核は最外側に位置する (写真 1 ). 中心域は細胞密度が高い.

n-SCS の細胞は単層に配列し，密にみられ細胞間 の境界は不明瞭である(写真 2$)$.

(2) 增殖期後期： $n-G C C の$ 柵状配列する最外層の 細胞の核は細胞の中心へ移動する傾向を示し，細胞質 は淡くめけてみ负，や豊富になる(写真 3 )。

n-SCSの細胞配列は密である(写真 4).

2）分泌期内膜

（1）分泌期前期：n-GCCの柵状配列する最外層の 細胞核の位置は集塊の中心域に向かって移動与る傾向 が著明になり，最外層の細胞質は淡くぬけてみえる。 また n-GCCの中心域の細胞密度も粗となる傾向を示 し，部分的に N/C比の低下とともに細胞集塊の全体 的な淡明化がみられる(写真 5 )。

n-SCS では, 細胞質の増加, N/C 比の低下, 細胞 密度の低下が認められる。核間距離の不揃い，核の大 小不同がうかがわ机る゙，核内クロマチンは微細で淡

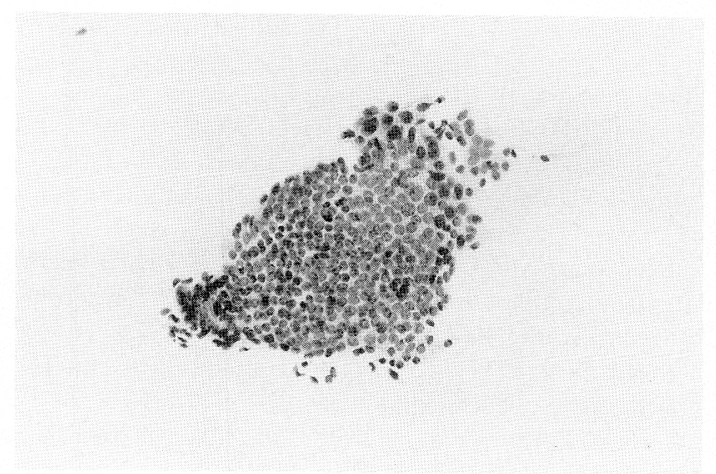

写真 2 増殖期前期、ジート状に配列する細胞の間隔は密であ る(Pap. 染色，×20） 


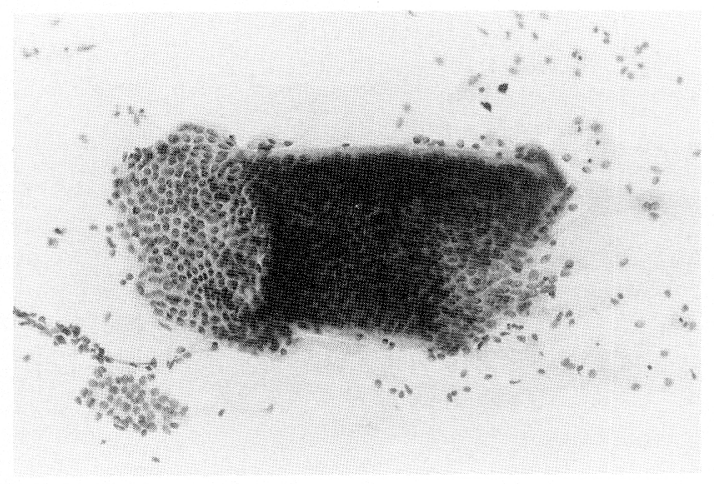

写真 3 増殖期後期。最外層に柵状配列する細胞の核は增殖期 前期に比べ細胞の中心側に寄る傾向を示す(Pap. 染 色. $\times 20)$

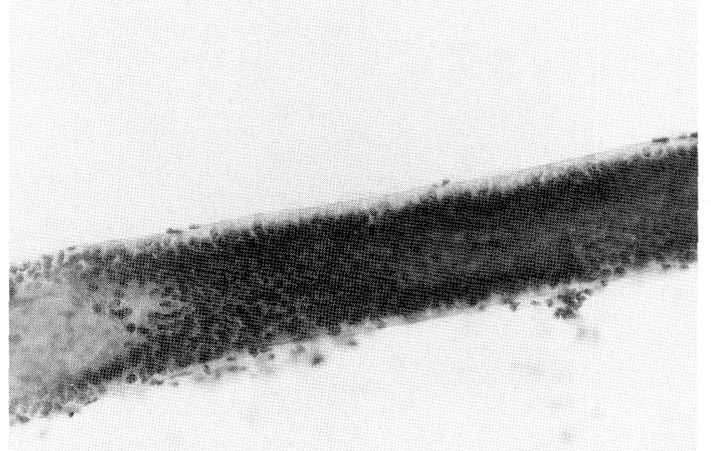

写真 5 分泌期前期. 最外層に柵状配列する細胞の核は増殖期 後期より細胞の中心側に位置することが多い

(Pap. 染色, $\times 20)$

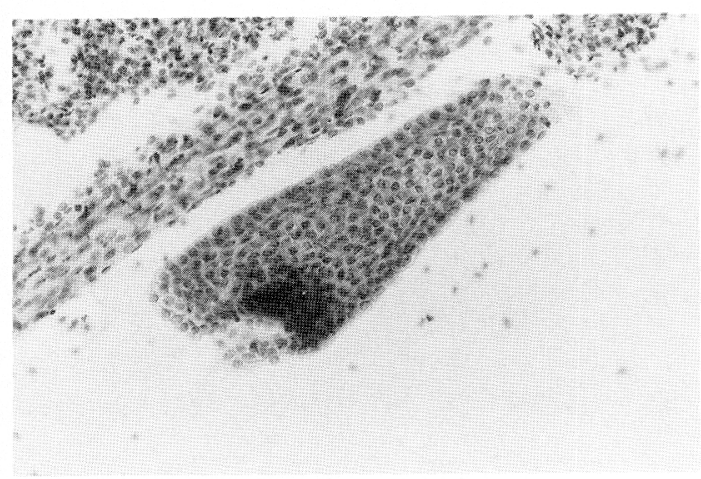

写真 7 分泌期中期. 最外層に栅状配列する細胞の核汸細胞集 塊の最外層側に寄名傾向を示す (Pap. 染色, ×20)

明となる (写真 6$)$.

(2) 分泌期中期：n-GCC は全体的に大型化し，形 状の不規則化がみられる。核の位置は種々であるが,

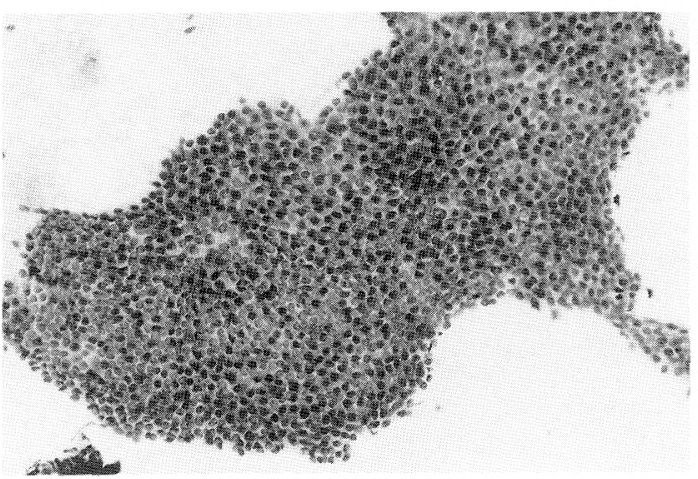

写真 4 増殖期後期、細胞の間隔はどの周期より密の傾向にあ る(Pap. 染色, $\times 20)$

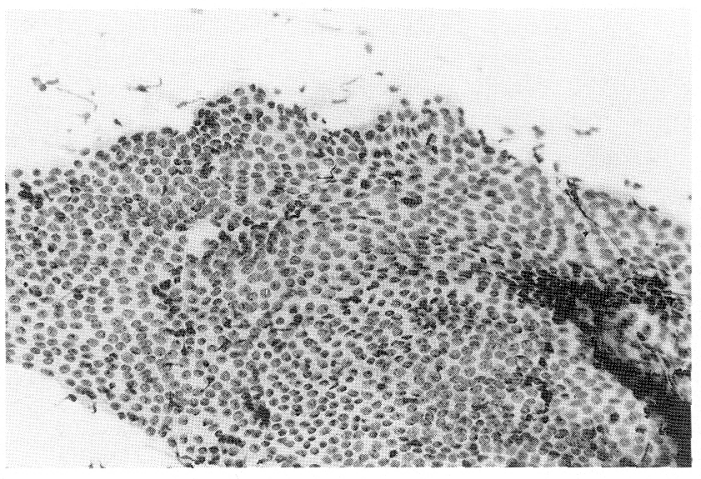

写真 6 分流期前期. 細胞間隔が広く，その境界が明らかにな り注じめる(Pap. 染色，×20)

分泌期前期に比し最外層に寄る傾向を示す（写真 7 ). n SCS の細胞間隔は広く, 細胞境界が明らかとな り，また細胞間の接着は強固であるため蜂巣状構造が みられてくる(写真 8$)$. 細胞核は腫大するが, 細胞 質も豊富なため N/C 比は小さくなる。

（3）分泌期後期：n-GCCの個々の細胞核は分泌中 期に比べ小型化傾向を示し， N/C 比は最も小さい。 n-GCC の最外層の細胞核は中期に比べ, さらに最外 側倚る傾向がみられる(写真 9 )。

n-SCS は蜂巣状構造がくずれるが，細胞境界は明 瞭であり，N/C比は最も小さく，核汸濃縮状となり 小型化する (写真 10)。

3) 閉経期内膜

n-GCC は閉経前に比べ集塊の境界抢よび柵状配列 が不明瞭で歪んだ形態が多く, 集塊の大きさは小型傾 向示す。細胞, 核間距離も不規則性を示し, 細胞間 の結合性が弱く, ルーズであり, 核は小型で濃縮傾向 を示す (写真 11). 


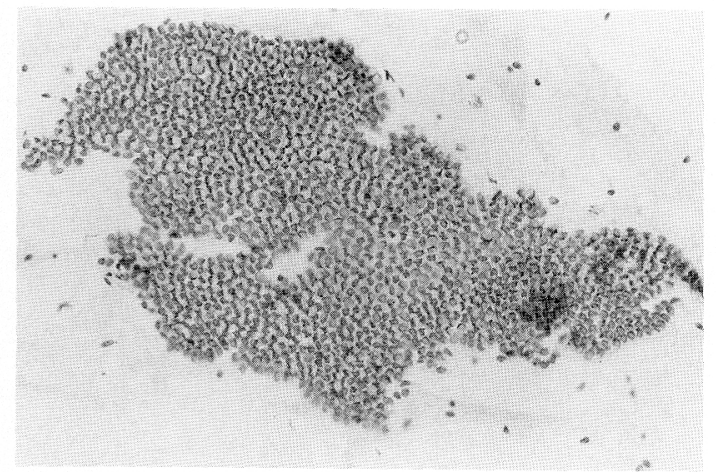

写真 8 分泌期中期. n-SCS 亿蜂巣状構造が著明になる (Pap, 染色, $\times 20)$

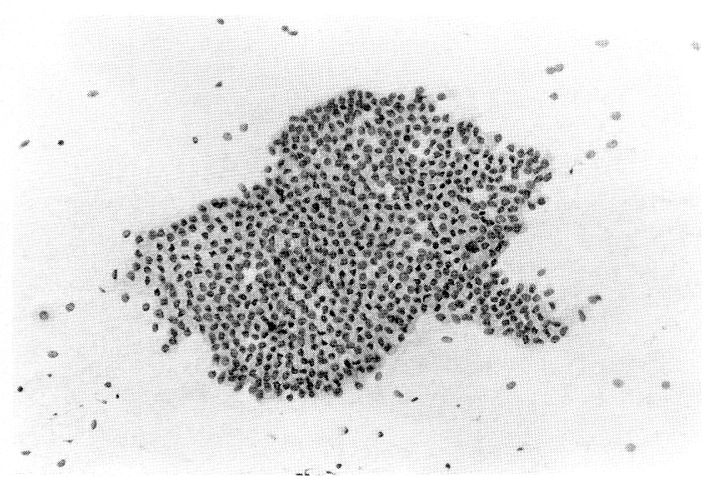

写真 10 分泌期後期. 核注小型傾向を示し, N/C 比は小さい (Pap. 染色， $\times 20)$

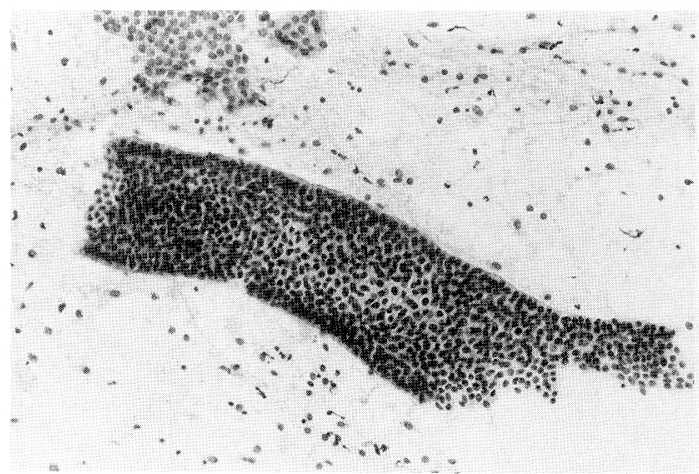

写真 9 分泌期後期. 最外層の細胞核は分泌期中期に比べ最外 層に寄る傾向がみられる（Pap. 染色，×20）

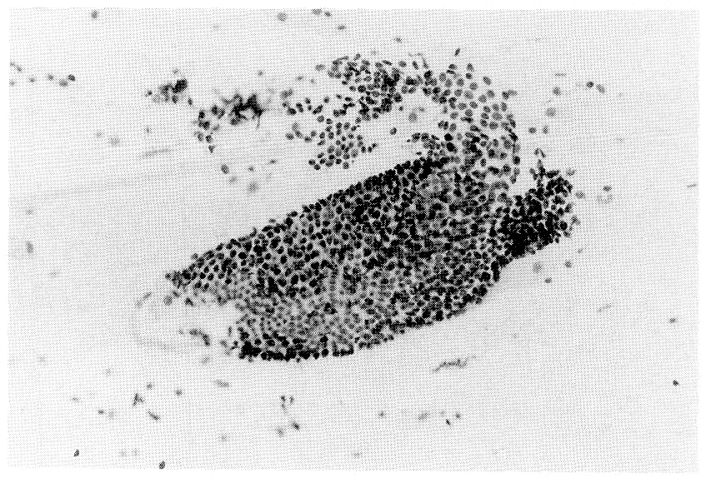

写真 11 閉経後. 閉経後の n-GCC は最外層に柵状配列する細 胞に乏しく，閉経前のn-GCCに比ベコンパクト感が 薄れる $($ Pap. 染色, $\times 20)$

表 1 年齢別 $n-G C C, n-S C S$ 平均出現数と出現率

\begin{tabular}{|c|c|c|c|c|c|c|}
\hline 年齢 & $20 \sim 29$ & $30 \sim 39$ & $40 \sim 49$ & $50 \sim 59$ & $60 \sim 69$ & $70 \sim$ \\
\hline 症例数 & 8 & 36 & 190 & 83 & 15 & 22 \\
\hline$n-G C C$ 平均出現数 & 9.0 & 10.5 & 9.7 & 5.0 & 0.8 & 1.2 \\
\hline n-SCS 平均出現数 & 111.7 & 147.3 & 167.3 & 169.1 & 52.2 & 69.0 \\
\hline $\mathrm{n}-G \mathrm{CCC}$ 平均出現率 $(\%)$ \% & 8.8 & 8.1 & 5.8 & 3.5 & 1.1 & 2.1 \\
\hline
\end{tabular}

*: n-GCC 出現数/ ( $\mathrm{n}-\mathrm{GCC}$ 出現数 $+n-\mathrm{SCS}$ 出現数)

\section{2. n-GCC と $\mathrm{n}-\mathrm{SCS}$ の出現数と頻度}

1) 年齢別の $\mathrm{n}-\mathrm{GCC}$ と $\mathrm{n}-\mathrm{SCS} の$ 平均出現数抒上 びn-GCC の出現率

22 歳から 79 歳までの計 354 例を 10 歳きざみの年 代別に検討した。各年代別の内膜細胞診標本の 1 枚女 たりに認められるn-GCC およびn-SCS の平均出現 数㔚よび全大型細胞塊( $\mathrm{n}-\mathrm{GCC}+\mathrm{n}-\mathrm{SCS})$ 中に占め る n-GCC の割合（n-GCC 出現率）を表 1 に示す。

n-GCC は20 歳代，30歳代，40歳代でそれぞれ
9.0 $, 10.5,9.7$ と他の年代に比べ高い数值を示し, 50 歳代以後漸減した。特に 60 歳代以後はそれぞれ顕 著に少なくなっていた。

20 歳代から 40 歳代までと，50歳代から 70 歳代ま での 2 群間の n-GCC 出現数の比較では, 前者に有意 に多かった $(\mathrm{P}<0.01)$.

n-SCS の出現数では, 20 歳代, 30 歳代, 40 歳代, 50 歳代ではそれぞれ，11.7，147.3，167.3ならびに 169.1 と高い数值示した。一方，60歳代，70歳代 
では低く,それぞれ 52.2,69.0を示した.なお, 20 歳代 から 50 歳代までと 60 歳代から 70 歳代までの 2 群間 の比較では後者に有意に低かった $(\mathrm{P}<0.01)$. その 出現数の低下はn-GCC の低下より一年代遅かった.

n-GCC と n-SCS を合わせた全大型細胞塊に対する n-GCC の出現数の比率は 20 歳代で最も多く, $8.8 \%$ を占めていた。また 40 歳代以後漸減傾向を示し, 60 歳代， 70 歳代ではそれぞれ $1.1 \% ， 2.1 \%$ であった. なお, 20 歳代から 40 歳代までと 50 歳代から 70 歳代 までの 2 群間の比較では, 後者で有意に低かった $(\mathrm{P}<0.01)$.

2）増殖期と分泌期における n-GCC と n-SCS の 平均出現数の比較

年齢が 50 歳以前で, 月経期, 月経直前期, 50 歳前 の閉経者を除いた 177 例を用いて, 標本 1 枚あたりに みられる $\mathrm{n}-\mathrm{GCC}, \mathrm{n}-\mathrm{SCS}$ の平均出現数を検討した (表 2 ). n-GCC の出現数は增殖期前期で 17.0 , 後期 で 12.3 を示し全体では 14.1 であった. 分泌期では前 期で 9.1 , 中期 7.8 , 後期で 4.3 , 全体では 7.5 を示 した. n-GCC の出現数は増殖期に多く, 分泌期の約 2 倍であり増殖期に有意に多かった $(\mathrm{p}<0.025)$. 一 方 n-SCS の出現数は n-GCC に比べ, 増殖期前期で は 230.4 , 後期で 172.7 全体として 201.5 であった。 分泌期前期では 135.4, 中期 177.8, 後期 175.2, 全 体としては 155.5 を示し，増殖期と分泌期の間で有意 差はみられなかった。

表 2 増殖期と分泌期に扔ける $n-G C C, n-S C S$ の平均出現数 と出現率

\begin{tabular}{rcccc}
\hline & 症例数 & $\begin{array}{c}\mathrm{n}-\mathrm{GCC} \text { 平均 } \\
\text { 出現数 }\end{array}$ & $\begin{array}{c}\mathrm{n}-\mathrm{SCS} \text { 平均 } \\
\text { 出現数 }\end{array}$ & $\begin{array}{c}\mathrm{n}-\mathrm{GCC} \text { 平均 } \\
\text { 出現率 }(\%)\end{array}$ \\
\hline 増殖期 & 90 & 14.1 & 201.5 & 6.8 \\
前期 & 34 & 17.0 & 230.4 & 5.9 \\
後期 & 56 & 12.3 & 172.7 & 7.6 \\
分泌期 & 87 & 7.5 & 155.5 & 5.2 \\
前期 & 43 & 9.1 & 135.4 & 6.8 \\
中期 & 25 & 7.8 & 177.8 & 4.3 \\
後期 & 19 & 4.3 & 175.2 & 4.6 \\
\hline
\end{tabular}

* $: n-G C C$ 出現数 $/(n-G C C$ 出現数 $+n-S C S$ 出現数 $)$

\section{3. 閉経前と閉経後における $\mathbf{n}-\mathbf{G C C}$ の平均出現数 と $\mathbf{n}-\mathrm{GCC}$ の平均出現率の比較}

閉経前とした症例は，年齢 48 歳まで，月経周期が 順調な症例を選択した。その 218 例の平均年齢は 43.6 歳であった。閉経後症例は年齢 50 歳以上, 1 年 以上月経が全くない症例とし，その 52 例の平均年齢 は 54.3 歳, その平均閉経後年数は 4.2 年であった. 閉経前症例の $\mathrm{n}-\mathrm{GCC}$ の平均出現数は 10.1 であっ た.これに比べ閉経後の n-GCC の平均出現数は 1.7 個と少なかった。n-GCC の出現率も，それぞれ 6.4, 1.37 を示し, 閉経後に低く両者で有意な差を示した $(\mathrm{p}<0.01)$ （表 3$)$.

\section{IV. 考察}

われわれの施設ではエンドサイト法を用いた ${ }^{4 \sim 7) 内 ~}$ 膜細胞診を実施しているが，この方法で採取された集 塊は, 内膜吸引細胞診法と比べ病理組織をよく反映し ており, 内膜細胞の構築を比較的よく保持している. また本法では細胞集塊が多数採取されるので，集塊を 重視して診断する機会の多い分化型子宮内膜腺癌の診 断には優れた方法でもある。特に高分化型腺癌例では 樹枝状集塊 ${ }^{8 \sim 10}$ が観察され, 本所見が診断の根拠とし て大きな比重を占めている。しかし樹枝状集塊がはっ きりしない不明膫な症例がときとして経験され, 出現 する集塊の異型がそしいこともあって満足し得る診断 を下せないことがある，そこでこのような症例の正診 率向上のためには, 正常例の細胞所見, 特に内膜細胞 塊を基礎的に把握しておくことが重要であろう.

無病正常症例に打けるn-GCC の出現数は 20 歳代 から 40 歳代まで著変はみられない. しかし 50 歳代を 境に以後加齢とともに減少する. 50 歳代以後の年代 では閉経期に入ることによって内膜機能層が萎縮する ため n-GCC が減少するのではないかと推測される. さらに 50 歳代以後の年代では細胞や核の萎縮ばかり でなく, 細胞間の結合が弱まるため, 細胞採取時に集 塊の原形がくずれて集塊として認識しにくくなること

表 3 閉経前後における $\mathrm{n}-\mathrm{GCC}, \mathrm{n}-\mathrm{SCS}$ の平均出現数と出現率

\begin{tabular}{lcccccc}
\hline & 症例数 & $\begin{array}{c}\mathrm{n}-\mathrm{GCC} \text { 平均 } \\
\text { 出現数 }\end{array}$ & $\begin{array}{c}\mathrm{n}-\mathrm{SCS} \text { 平均 } \\
\text { 出現数 }\end{array}$ & $\begin{array}{c}\mathrm{n}-\mathrm{GCC} \text { 平均 } \\
\text { 出現率 }(\%)\end{array}$ & $\begin{array}{c}\text { 平均 } \\
\text { 年齢 }\end{array}$ & $\begin{array}{c}\text { 閉経後 } \\
\text { 平均年数 }\end{array}$ \\
\hline 閉経前 & 218 & 10.1 & 162.6 & 6.4 & 43.6 & - \\
閉経後 & 52 & 1.7 & 106.5 & 1.37 & 54.3 & 4.2 \\
\hline
\end{tabular}

* $: n-G C C$ 出現数/ (n-GCC 出現数 $+n-S C S$ 出現数 $)$ 
も 1 つの要因であろう.

またn-SCS とn-GCC の出現数を年代別に比較す ると, n-SCS が n-GCC より一年代遅くまで認められ る.これは機能層の導管上皮の変化が被覆上皮の萎縮 性変化に比べ，早期に始まり，そのためn-GCCが n-SCS より早く減少するのではないかと推測される. そしてその期間は約 10 年と考えられる.

性周期別における $\mathrm{n}-\mathrm{GCC}$ の出現数は増殖期前期で ピークを示し, 以後, 分泌期後期まで減少傾向をたど る. 基本的に腺管の数は, 両者とも増殖期と比較し て, 分泌期も同じで変わることはないであろう。にも かかわらず，増殖期に多く認められる一因として，腺 管の太さが増殖期で細く, 直線的であるのに比べ, 分

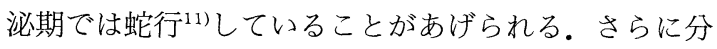
泌期では細胞質が広く，また，互いの結合がゆるやか であるため細胞間の距離が不均一となって筒状の原形 がくずれやすくなるため, われわれが規定した $\mathrm{n}$ GCC の範囲に入らない n-GCC もみられるのではな かろうか。一般に，分泌期では，粘液成分を多く含む 腺上皮細胞と浮腫性となった間質細胞との鑑別が難し いことが少なくない，という事実も影響を与えている かもしれない.

分泌期や増殖期に比べ閉経期では，n-GCC は極端 に少なかった。同時にn-SCS も減少していた。これ は内膜組織の萎縮性変化, 内膜腺の減少によるもので あろう。

以上，無病正常症例に扔ける，内膜細胞集塊の形態 と出現数, 出現率を分析し検討した. 正常症例の内膜 細胞, 特に集塊を正確に把握することは, 分化型子宮 内膜癌や子宮内膜異型増殖症などの内膜細胞診正診率 の向上に役立つと考える.

\section{Summary}

Normal glandular cell clusters ( $\mathrm{n}-\mathrm{GCC}$ ) and normal stromal cell sheets ( $n$-SCS) were identified in endometrial cell samples, from normal females, obtained at Kitasato Medical Center Hospital, and their numbers and frequencies per slide were measured. The following results were obtained.

1) When analyzed according to age group among 354 cases, n-GCC was higher in occurrence in the groups composed of women in their $20 \mathrm{~s}, 30 \mathrm{~s}$ and $40 \mathrm{~s}$ than that of women in their $50 \mathrm{~s}$ or older $(\mathrm{p}<0.01)$. $\mathrm{n}$-SCS also decreased in those in their $60 \mathrm{~s}$, but was one decade later $(\mathrm{p}<0.01)$.
2) When analyzed according to menstrual cycle among 177 cases, cells in the proliferative phase showed greater preservation of $\mathrm{n}-\mathrm{GCC}$ than those in the secretory phase $(\mathrm{p}<$ $0.025)$.

3) Depending on the pre-or post-menopausal state of 270 cases, the mean number of $n-G C C$ in post-menopausal woman was 1.7 , but was 10.1 in pre-menopausal one $(\mathrm{p}<$ $0.01)$.

It is worthwhile to identify n-GCC and n-SCS from the cellular group of normal endometrial cytology in order to make a differential diagnosis of endometrial neoplasias such as atypical hyperplasia and G1 adenocarcinoma which are difficult to diagnose cytologically.

\section{文献}

1) Reagan, J.W. Can screeing for endometrial cancer be justified?. Acta Cytol $1980 ; 24: 87 \sim 89$.

2) 蔵本博行. 子宮体癌検診. 東京: 医師薬出版, $1988: 36$ $\sim 37$.

3）鳥居貴代, 布引 治, 甲斐美咲, 野田 定. 子宮内膜細 胞診における性周期推定に関する研究. 日臨細胞誌 $1994 ; 33: 604 \sim 611$.

4）藤田 涁, 藤原富子, 渡辺精子, 堤嶋真人, 上坂佳敬, 綿貫＼cjkstart勤・ほか. エンドサイト法による子宮内膜細胞診 の検討. 日臨細胞誌 $1990 ； 29: 8 \sim 15$.

5）井上芳樹, 服部 浩, 堀井高久, 野田起一郎. Endocyteによる体癌のスクリーニング。産と婦 1982 ; $49: 1443 \sim 1447$.

6) 谷口一郎, 荷見勝彦, 神谷 稔, 高橋 稔, 小林拓郎, 村上 俊一・ほか. 子宮内膜細胞診における Endocyte 法と増淵 式吸引法との比較. 日産婦誌 $1982 ； 34: 1746 \sim 1754$.

7）森沢孝行, 蔵本博行, 上坊敏子, 加藤良樹, 脇田邦夫. 子宮内膜細胞診の新しい擦過採取法について. 日臨細胞 誌 $1982 ； 21: 520 \sim 525$.

8）大野英治, 藏本博行. 細胞診による子宮体癌の組織分化 度判定. 日臨細胞誌 $1988 ； 27: 449 \sim 458$.

9）石井保吉, 藤井雅彦, 佐久間市朗, 桐谷寿子, 小宮山京 子, 若林富枝 - ほか. 内膜細胞診における腺腫性増殖症 および G 1 腺癌の判定基準について（第 II 報）一細胞集 塊の構造異型を中心に一. 日臨細胞誌 $1991 ; 30 ： 1043$ $\sim 1049$.

10）則松良明, 香田浩美, 浜崎周次, 尾関祐里, 中国泰美, 古谷満寿美 - ほか. 子宮内膜細胞診における正常内膜, 腺腫性増殖症, 高分化型腺癌の細胞学的検討一細胞集塊 形態の比較を中心に一. $1995 ; 34: 439 \sim 448$.

11）桜井幹巳. 子宮体部. 宮地 徹, 森脇昭介, 産婦人科病 理学診断図譜, 東京: 杏林書院, 1987：152 174. 